\title{
Criminality, Human Capital and Economic Performance
}

\author{
Adla Mokline \\ Fseg Sousse, Sousse University, Tunisia \\ E-mail: adlamokline@gmail.com
}

Received: September 20, 2018 Accepted: October 3, 2018 Published: November 22, 2018

doi:10.5296/ber.v8i4.13948

URL: https://doi.org/10.5296/ber.v8i4.13948

\begin{abstract}
Criminality is any breach of the law likely to give rise to legal proceedings. It is determined by several factors namely (population density- unemployment-income- poverty and education). The objective of our work is to study criminality determinants on a sample of 51 American States over the period (2000-2013). Particular attention is paid to study the causal relationship between education (with its different measures) and criminality.

In line with the approach to the economics of crime, this paper attempts to verify that urbanization, income inequality, unemployment, poverty and educational attainment significantly explain crime, on the one hand, and education is an investment activity that produces human capital, which is a fundamental factor of economic growth, job creation, wages and increased productivity of factors of production.

Our results showed that the investment in human capital has a negative impact on crime in general. This effect is more considerable on crime against property. This leads us to define a crime deterrence policy through the implementation of structures able to help with installation of young people out of school and increase public spending on education.
\end{abstract}

Keywords: Economics of crime, Crime model, Human capital, Policy of deterrence, Panel data

\section{Introduction}

The relationships between law and economy have never been excluded from the concerns of economics. History points out that we cannot unravel the legal and the economic. Both disciplines indeed independent have in common several societal areas of interest (property, health, transport and criminality). The economic analysis of crime is a vast and rich subject to which numerous economists participated. It is in end of the 1960s that the economists started to adopt certain economic techniques to study the criminal phenomenon. G. Becker (1968) article remains until today a reference model of crime economy. In his model, the criminal is considered as a rational individual and the criminal decision as the result of cost-benefit 
analysis (the means of committing the act- the probability of arrest and conviction- the severity of the sentence). The individual accepts to transgress the law if its mathematical expectation of utility exceeds that of legal activity utility. The individuals become delinquent, not due to their basic motivation, but because their cost and advantages are different.

The criminal behavior is apprehended in a framework of offers and requests: Criminal individuals offer crime, community asks for protection offered by the state. Within this framework, individuals respond differently to State incentives. The latter affects the form of deterrence variables such as the probability of arrest and conviction and the severity of the sentence.

G. Becker model shows the criminal will be more or less sensitive to regression variables according to his/her attitude facing the risk so that globally an increase in the severity of the sentence has a negative effect on crime offer. However, the increase in the probability of arrest has no effect on individuals who like the risk.

His model doesn't include recurrence and remains too static. The first limit is overcome by J. Harris (1970) who supposes that the first offence falls under an economic calculation and that recurrence arises only from policies of repression effective choices. The second limit is exceeded by D. Sojoquist (1973), who considers that the gain from criminal activity is function of preparation and execution of crime time.

I. Erlich (1973) improves the approach and presents the criminal decision problem as an optimal allocation problem of resources between legal and illegal activities.

Likewise, the law effectiveness weaves the fundamental link between economic and legal systems. The criminal law appears as a program that society can manipulate in order to reduce the social cost of law and administration of justice. Whatever the criteria taken into account by community: revenge, dissuasion, rehabilitation, repair, rare resources are used submitting the application of law to the principle of rarity.

Policies activity against crime depends on the efficiency of direct prevention and regression dispenses, but it should also appreciate according to alternative methods.

Once the crime is partially conditioned by income inequalities, there is a social incentive to equalize training opportunities and profits independently of ethnic considerations and/or choice of social welfare function. In general, the focus should be put on criminality economic determinants. Economic planning must take into account criminogenic factors inherent in economic development in order to prevent. Indeed, the incentive to participate and stay in the illegal practice depends on costs «of the ways that open to an individual. The legal project is favored by a decline of the gap between illegitimate and licit gains, by a reduction of the possibility of unemployment or by an increase of its compensation to the extent that the value of time is linked with the individual richness, his/her income, these variables may disrupt the fields of choice possibilities.

\section{Theoretical Foundations of Crime Determination Model}

The development of crime determination model leads us to present the model different 
variables, on the one hand and to specify the model on the other.

\subsection{The Problem of Crime in the Economic Literature}

The economic literature presents a wide debate on these determinants influence on the individual criminality.

The amount of transferable property, the total income through a community are precious indicators for the study of crime. Individuals whose legal income is below the average income of the community are confronted with more interesting earnings differentials in crime. According to the sentence measured in monetary units (fine) or in time units (prison sentence), the effect of wealth on the criminal decision oscillates between the positive and negative effect. According to Becker (1968), Ehrlich (1973), Grogger (1998) and Kelly (2000), individuals whose income level is low, accept the execution of a criminal activity as a lucrative activity.

Individuals are engaged in their income and social positions interpersonal comparisons which will generate a feeling of deprivation or relative satisfaction according to the «place» of the individual in society, as a choice to reduce the feeling of relative deprivation, crime can be seen as a means to increase income and improve social position following a significant relative gain in these activities and a lower cost of incarceration.

The degree of urbanization can also be retained among the elements favoring crime against goods and people. Its action can spread through accessibility to goods and people at a lower cost following the concentration of industrial and commercial activities, the population density and probably also because the anonymity of cities favors more the clandestinity of offenses.

The effect of population density is linked to poverty phenomenon. The rich households are sensitive to urban delinquency, leading to the depopulation of rich households. However, poverty effect remains more or less ambiguous. The predictions of Beckerien model on criminality determinants remain a major reference. As for population density, Becker in his works shows that crime is a phenomenon is a typically urban phenomenon. Glaser and Sucerdate (1995) show that the same results are checked especially for the damages of property and less for violent crime against people.

Unemployment is considered like a motivating factor of crime offer in this case; the crime offer function is treated by analogy with the job offer in the different jobs. According to Becker (1968) T.Chiricos (1987) and Scholler (1994), the unemployed who cannot derive any consequent income from legal work (apart from unemployment benefit) would be encouraged to engage in illicit activities.

Contemporary economists, such as endogenous growth theorists were more particularly interested in the role played by education in crime reduction at the same time as externality of human capital and civic externality.

Education may be a decriminalization factor. It favors the increase of the individual time in all legal activities. It's considered as a «profitable». Crime reduction by education is 
considered as an important externality and socially beneficent at the microeconomic and macroeconomic levels, despite the increase in public and private spending. Lochner and Mirotti (2004) and F.Puech (2005) show that education exerts three external effects on crime:

- Civic externality that rests on the contribution of Usher, leads to the fact that the increase in the level of education may result in increased crime opportunity cost. The individual whose education level is high doesn't accept the execution of the crime. According to this author, the social return of education is much higher than private return. The sentence cost becomes more expensive. S/He risks then to lose his/her job, salary, social status.

- Pecuniary externality leads to the fact that the investment in the human capital increases legal work, in this case, the individual becomes more productive and obtains a higher salary corresponding to his/her education level.

- Social externality via inequalities of income: this externality helps to strengthen social cohesion between individuals especially in the presence of inequalities of income between educated and less educated individuals. Thanks to this effect, the feeling of frustration and relative privation decreases to reach the relative degree of satisfaction developed in Fajnzleber (2002). Education may act as a public action forbidding crime.

I.Ehrlich (1975), Lochner (1999) developed models studying crime-education relationship (schooling- qualification- training). They concluded that the only individual whose educational level is low commits more crime. They cannot conclude the opposite effect of education on crime that is «white-collar crime».

Education is not devoid of negative effects, it can be criminogenic. Marc Gendron (2007) tried to develop a model explaining how an important layer of society, which has never been considered as criminal, exerts this type of delinquency. In his work, Marc Gendron shows that the accumulation of human capital via education the execution of a criminal act during legal work, reducing the probability of arrest and the conviction of fraudulent action. It is then about a crime committed during a professional function (misappropriation of funds falsification of accounting records). «White-collar crime» increases with the individual level of education insofar as the individual doesn't lose his/her legal work at the moment where s/he commits her/his crime. Thanks to his/her high education level, the individual can his/her criminal actions in the absence of detection and conviction.

These policies privileged the repressive aspects (increase of domestic security spending). The dissuasive policy didn't have the expected scope since crime continued to grow in number and violence. It was then necessary to accompany repressive policy with a social policy combining fight against poverty, inequalities in income, unemployment and marginalization.

Major economists agree on the fact that education acts as a composite instrument able to reduce the advanced pains. It would be appropriate to privilege education as a tool of fight against crime. The present reflection will endeavor to verify the hypothesis according to which urbanization, unemployment, income and poverty explain significantly crime and to compare the theoretical results focusing on education as an element occupying an axiological 
position in the treatment of crime.

The question arises about identifying the determinants of crime in the framework of the United-States. Specifically, what is the sense of causality of crime-education relationship?

\subsection{Model Specification}

To validate our hypothesis, that human capital accumulation via education may be an effective way of determining the individual choice between legal and illegal activities, it is an effective to reduce crime within society.

We had recourse to an American database made from US census data from 2000 to 2013. Our sample is composed of 50 American states and one district over 14 years. For states, we have the same observation period, giving us a cubic panel.

Our estimation model is written as follows:

$$
(\mathrm{Cr})_{\mathrm{i}, \mathrm{t}}=\alpha_{0}+\alpha_{1}(\text { pop })_{\mathrm{i}, \mathrm{t}}+\alpha_{2}(\mathrm{ed})_{\mathrm{i}, \mathrm{t}}+\alpha_{3}(\mathrm{rev})_{\mathrm{i}, \mathrm{t}}+\alpha_{4}(\mathrm{ch})_{\mathrm{i}, \mathrm{t}}+\alpha_{5}(\mathrm{pt})_{\mathrm{i}, \mathrm{t}}+\varepsilon_{\mathrm{i}, \mathrm{t}}
$$

In this model, $(\mathrm{Cr})_{\mathrm{i}, \mathrm{t}}$ variable represents the number of criminal acts in the State I by year. It integrates all violations of law likely to give rise to legal prosecutions. The determination of the total number of illicit acts takes into account crime against people (murder, rape, aggression) and crime against property (home theft, car theft).

(Pop $)_{\mathrm{i}, \mathrm{t}}$ : density of the population aged between 25 and 34. It's the most concerned population in the Bekerian model. This variable tells us about the effect of urbanization degree on crime against goods and people. (Ed) ${ }_{i, t}$ : The part of the population aged between 25 and 34 according to educational level (primary, secondary or higher). The choice of human capital accumulation (education with its three levels) appears justified. This variable tells us about the degree of efficiency of government intervention as regards to crime deterrence. $(\operatorname{Rev})_{\mathrm{i}, \mathrm{t}}$ : The Personal income per capita and by state i ( per Capita Personal Income by State) at year t. $(\mathrm{Ch})_{\mathrm{i}, \mathrm{t}}$ : Unemployment volume for the state $\mathrm{i}$ at year $\mathrm{t} .(\mathrm{pt})_{\mathrm{i}, \mathrm{t}}$ : the volume of poverty for the state $\mathrm{i}$ at the year $\mathrm{t}$.

For the United-States and taking into account observation period, we opt for a modeling in panel data. Therefore, the index i will be characteristic of the states and the index t of the year. This model could be «increased» by introducing an additional variable namely, income inequalities. These ones being measured by Gini coefficient, it indicates the measure in which the distribution of the household income from the uniform distribution. In our model, we ignore this variable for two reasons:*It is not available for all the American sates of our sample *International comparisons of income inequalities via Gini index are difficult to interpret.

With the aim of handling significantly the impacts of socioeconomic and demographic variables on crime evolution, we will adopt the following methodology:

In a first phase, we test the effects of the socioeconomic and demographic variables on total crime variation, by granting a particular articulation to the effects of education and human capital accumulation on total crime. 


\section{Macrothink}

Business and Economic Research ISSN 2162-4860 2018, Vol. 8, No. 4

These texts will be led separately for each education level, in order to identify specific results for education primary effects $\left(\mathrm{ed}_{1}\right)$, for secondary education $\left(\mathrm{ed}_{2}\right)$ and finally higher education $\left(\mathrm{ed}_{3}\right)$.

$$
\begin{aligned}
& (\mathrm{Cr})_{\mathrm{i}, \mathrm{t}}=\alpha_{0}+\alpha_{1}(\mathrm{pop})_{\mathrm{i}, \mathrm{t}}+\alpha_{2}\left(\mathrm{ed}_{1}\right)_{\mathrm{i}, \mathrm{t}}+\alpha_{3}(\mathrm{rev})_{\mathrm{i}, \mathrm{t}}+\alpha_{4}(\mathrm{ch})_{\mathrm{i}, \mathrm{t}}+\alpha_{5}(\mathrm{pt})_{\mathrm{i}, \mathrm{t}}+\varepsilon_{\mathrm{i}, \mathrm{t}} \\
& (\mathrm{Cr})_{\mathrm{i}, \mathrm{t}}=\alpha_{0}+\alpha_{1}(\mathrm{pop})_{\mathrm{i}, \mathrm{t}}+\alpha_{2}\left(\mathrm{ed}_{2}\right)_{\mathrm{i}, \mathrm{t}}+\alpha_{3}(\mathrm{rev})_{\mathrm{i}, \mathrm{t}}+\alpha_{4}(\mathrm{ch})_{\mathrm{i}, \mathrm{t}}+\alpha_{5}(\mathrm{pt})_{\mathrm{i}, \mathrm{t}}+\varepsilon_{\mathrm{i}, \mathrm{t}} \\
& (\mathrm{Cr})_{\mathrm{i}, \mathrm{t}}=\alpha_{0}+\alpha_{1}(\mathrm{pop})_{\mathrm{i}, \mathrm{t}}+\alpha_{2}\left(\mathrm{ed}_{3}\right)_{\mathrm{i}, \mathrm{t}}+\alpha_{3}(\mathrm{rev})_{\mathrm{i}, \mathrm{t}}+\alpha_{4}(\mathrm{ch})_{\mathrm{i}, \mathrm{t}}+\alpha_{5}(\mathrm{pt})_{\mathrm{i}, \mathrm{t}}+\varepsilon_{\mathrm{i}, \mathrm{t}}
\end{aligned}
$$

Secondly, the effects of socioeconomic factors in the theoretical part assimilated to determinants on the behavior of crime taken in its two forms: crime vote (Crp) and economic crime (Crpr)

$$
\begin{aligned}
& (\text { Crpr })_{i, t}=\alpha_{0}+\alpha_{1}(\text { pop })_{i, t}+\alpha_{2}(\text { ed })_{i, t}+\alpha_{3}(\text { rev })_{i, t}+\alpha_{4}(\text { ch })_{i, t}+\alpha_{5}(\text { pt })_{i, t}+\varepsilon_{i, t} \\
& (\operatorname{Crp})_{\mathrm{i}, \mathrm{t}}=\alpha_{0}+\alpha_{1}(\mathrm{pop})_{\mathrm{i}, \mathrm{t}}+\alpha_{2}(\mathrm{ed})_{\mathrm{i}, \mathrm{t}}+\alpha_{3}(\mathrm{rev})_{\mathrm{i}, \mathrm{t}}+\alpha_{4}(\mathrm{ch})_{\mathrm{i}, \mathrm{t}}+\alpha_{5}(\mathrm{pt})_{\mathrm{i}, \mathrm{t}}+\varepsilon_{\mathrm{i}, \mathrm{t}}
\end{aligned}
$$

\section{The Sense of Causality of the Crime Education Relationship}

After having operated the tests of specificity, stationarity, robustness, we note, in a comprehensive manner, the results of estimation we reached are relatively in accordance with in accordance with the predictions of the theoretical models. The results allowed us to validate, on the one hand the effects of socioeconomic and demographic variables on criminal decision and on the other hand, to check the meaning of the relationship between education and crime.

Our intuition is then to know the weight of government and its ability to fight against public disorder (any kind of crime) by applying an accumulation strategy of human capital. The statistics found appear in the following table:

\subsection{Empirical Results and Their Interpretations}

First and foremost, it is worth taking a critical look at the data we have. A summary in the table below;

Table 1. Effects of education on total crime

\begin{tabular}{|l|l|l|l|}
\hline Dependent variable Cr & Modal 4-1-a With ed & Modal 4-1-b with ed & Modal4-1-c with ed \\
\hline Pop & 0,0323334 & 0,0334874 & 0,0333844 \\
& $(0,000)^{* * *}$ & $(0,000)^{* * *}$ & $(0,000)^{* * *}$ \\
\hline ed $_{1}$ & 0,2054626 & & \\
& $(0,287)$ & ----------------- & ----------------- \\
\hline ed $_{2}$ & & $-0,1112372$ & \\
& ----------------- & $(0,013)^{* *}$ & ----------------- \\
\hline ed $_{3}$ & & & $-0,4564565$ \\
& ---------------- & ---------------- & $(0,050)^{* *}$ \\
\hline Rev & 0,6847853 & 0,6736388 & 0,6577054 \\
& $(0,172)$ & $(0,169)$ & $(0,178)$ \\
\hline Ch & 0,0199513 & 0,0199713 & 0,0158113 \\
& $(0,000)^{* * *}$ & $(0,000)^{* * *}$ & $(0,000)^{* * *}$ \\
\hline Pt & 0,0089556 & 0,0852518 & 0,0603876 \\
& $(0,027)^{* *}$ & $(0,055)^{*}$ & $(0,225)$ \\
\hline
\end{tabular}


\begin{tabular}{|l|l|l|l|}
\hline Number of observations & 710 & 710 & 710 \\
\hline
\end{tabular}

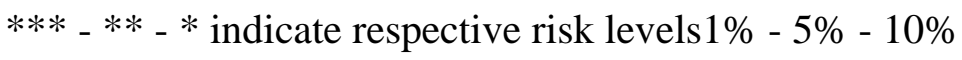

- For population density variable: urbanization measured by the population density is statistically and significantly positive with crime.

This suggests that, in the different states, the more the volume of urban population increases, the more the number of criminal acts increases. This result is checked in most of empirical studies and also confirms the Beckerian model predictions which show that crime is a uniquely urban phenomenon.

- For income variable: The variation of income doesn't explain the rise of crime.

- Certain studies reject the hypothesis of crime sensitivity to income and this could be explained by the fact that the income measures used in empirical studies integrate not only legal income but also illicit gains coming from non-sentenced and sanctioned activities (in this case, the illegal income becomes more motivating and attracting). Therefore, the effect of income is biased because of the existence of a strong correlation between legal and illegal incomes. The associated coefficient sign to income variable is positive but not significant. The positive sign confirms Fajnzber (2002)'s work, who shows that an average income means the opportunity increase for criminals. However, the lack of significance of this variable effect on crime opposes the works of Becker (1968), Ehrlich (1973) and Grogger (1998), who concluded that criminal activity is a lucrative activity.

- For unemployment variable: We notice that unemployment has a positive and statistically significant effect on crime. This result cancels the work of R.Carr Hill (1987) Freeman (1995) checking the negative effect of unemployment on crime. And this is explained by the fact that parents living in situation of unemployment would be more warned and sensitive towards a participation of their children in criminal activities whose probability of arrest and condemnation is high. These parents are then unable to suffer the consequences of any arrest or condemnation. By referring to the theoretical literature about the effect of unemployment on crime, our result (in three types of regression) proves conclusive. Indeed, these theories provide at least three reasons explaining why unemployment affects positively crime in general.

First of all, according to Becker (1968), the unemployed who don't manage to get a legal income (in the absence of unemployment benefit) would be more incited to illegal work. Second, according to Scholler (1994), the situation of unemployment influences the calculation of an individual supposed to be rational via the expected value of gain and pushes him/her to participate in delinquency. Third, according to Hichri (1965), an acute unemployment R.Carr Hill (1987) et Freeman (1995) accompanied with a negative situation (absence of respect and confidence) can only be a source of development and delinquency.

- For primary education variable $\left(\mathbf{e d}_{1}\right)$ : Primary education variable $\left(\operatorname{ed}_{1}\right)$ has no significant effect on crime and this is explained by the fact that the essential of the effect 
of education on crime comes from the increase in the proportion of salary. Indeed, an individual whose level of education is low (primary) is unlikely to find a well paid legal work. Therefore, he/she finds him/her self obliged to execute a non-profit criminal act.

The behavior of an individual whose primary education level is ambiguous that's to say other variables should be introduced to explain his/her behavior towards crimes such as social and family environment.

In the second regression, we notice that secondary education has a statistically significant negative effect on crime. The higher the level of secondary education increases, the more the decision of performing a criminal act decreases as opposed to the first regression with only a primary education level. This result confirms the empirical works carried out by Lochner and Moretti (2004) and Puech (2005).

The Introduction of a higher education level $\left(\mathbf{e d}_{3}\right)$ in the third regression has also a statistically negative effect on crime. This result corroborates many empirical works. Grogger (1998), for example, explains the negative effect of higher education by an indirect effect (via the increase of salary). The introduction of $\left(\mathrm{ed}_{3}\right)$ highlights the three externalities (pecuniary externality-civic externality- social externality via the action of action inequalities of income). Usher (1997) suggests an alternative explanation concerning the effect of education (especially higher) on crime. According to this author, education social return is higher than the return coming from illicit gains. Education produces then good citizens and accumulates common social norms to respect. Thanks to these externalities, education creates a coherent society. The accumulation of human capital (especially public education) can then be considered as a crime element.

This result cripples some work: Education may be linked with delinquency by tax frauds, illicit commercial practices. That is to say the set of crimes said «white collar crimes». Lochner and Moretti showed, based on microeconomic data (dealing with American prisoners), that education can increase white collar crimes «crime committed during his/her professional function by a responsible person with high social status» Suther Land (1949).These results show authority and power of the state to give programs for fight against criminality within the different states of our sample.

Accumulation of human capital does it affect more economic crime (against property) than violent crime (against people)? Public expenses of education are they able to reduce illiteracy rate and thus reduce crime rate?

To answer these questions, a more comprehensive study is to test each measure ( $\left.\mathrm{ed}_{1}, \mathrm{ed} 2, \mathrm{ed}_{3}\right)$ to estimate the effect separately of each education level on crime against people and on crime against property. 
Table 2. Effects of education on crime against people

\begin{tabular}{|c|c|c|c|}
\hline Variable dépendante $\mathrm{Crp}$ & Modèle 4-2-a avec ed ${ }_{1}$ & Modèle 4-2-b avec ed ${ }_{2}$ & Modèle 4-2-c avec ed 3 \\
\hline Pop & $\begin{array}{l}0,0043257 \\
(0,000)^{* * *}\end{array}$ & $\begin{array}{l}0,0045731 \\
(0,000) * * *\end{array}$ & $\begin{array}{l}0,0044923 \\
(0,000) * * *\end{array}$ \\
\hline $\mathrm{ed}_{1}$ & $\begin{array}{l}0,0750693 \\
(0,032)^{* *}\end{array}$ & --------------------- & --------------------- \\
\hline $\mathrm{ed}_{2}$ & --------------------- & $\begin{array}{l}-0,0274459 \\
(0,001)^{* * *}\end{array}$ & \\
\hline $\mathrm{ed}_{3}$ & 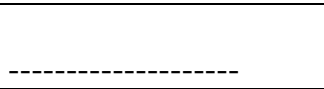 & 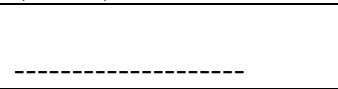 & $\begin{array}{l}-0,1163808 \\
(0,000)^{* * * *}\end{array}$ \\
\hline Rev & $\begin{array}{l}0,0862361 \\
(0,174)\end{array}$ & $\begin{array}{l}0,0864297 \\
(0,164)\end{array}$ & $\begin{array}{l}0,083156 \\
(0,180)\end{array}$ \\
\hline $\mathrm{Ch}$ & $\begin{array}{l}0,0029413 \\
(0,000)^{* * *}\end{array}$ & $\begin{array}{l}0,0032636 \\
(0,000) * * *\end{array}$ & $\begin{array}{l}0,0022313 \\
(0,000) * * *\end{array}$ \\
\hline $\mathrm{Pt}$ & $\begin{array}{l}0,064262 \\
(0,234)\end{array}$ & $\begin{array}{l}0,060936 \\
(0,327)\end{array}$ & $\begin{array}{l}0,029626 \\
(0,966)\end{array}$ \\
\hline Number of observations & 710 & 710 & 710 \\
\hline
\end{tabular}

$* * * *_{-} * *_{-} *$ indicate respective risk levels $1 \%-5 \%-10 \%$

- For income variable: The variation of income always remains ineffective on crime in general and against crime on people in particular. According to F. Puech, the non-significance of income variable in a model of crime regression strengthens the intuition that crime against people depends essentially on the individual social and moral values.

- For primary education variable: The primary education variable has a positive effect on crime against people and against property.

- For secondary education and higher education: A higher education level $\left(\mathrm{ed}_{2}\right.$ then $\mathrm{ed}_{3}$ ) reduces crime against people. This result confirms the works of Lochner and Moretti (2004) and F.Puech (2005). We notice that the higher e level of education increases, the more its deterrent effect on crime against people increases. That's to say the higher level of education has a higher effect $(-0,1163808)$ than that of the secondary education (-0, 0274459). This result highlights civic externality of education via the increase of crime opportunity cost. The individual whose education is high (with a higher level of education ed ${ }_{3}$ ) doesn't accept the execution of a criminal act, s/he risks to lose her/his salary and her/his social status. This result is similar to an interpretation proposed by Usher (1997) «Education exerts a deterrent effect on violence via the civic externality it generates».

Education may lead therefore to crime moral cost and acts thus as public crime deterrence. These results are they the same in the case of crime against property? The estimation below allows testing the sensitivity of crime against property to socioeconomic, demographic and education variables. 
Table 3. Effects of education on total crime

\begin{tabular}{|l|l|l|l|}
\hline Dependent Variable Crpr & Modal 4-3-a with ed & Modal 4-3-b withed & Modal 4-3-c withed $_{3}$ \\
\hline Pop & 0,0281424 & 0,0290027 & 0,0289277 \\
& $(0,000)^{* * *}$ & $(0,000)^{* * *}$ & $(0,000)^{* * *}$ \\
\hline ed $_{1}$ & 0,1558226 & & \\
& $(0,338)$ & ---------------- & ---------------- \\
\hline ed $_{2}$ & & $-0,0841608$ & \\
& --------------- & $(0,025)^{* *}$ & - \\
\hline ed $_{3}$ & & & $-0,36107764$ \\
& ---------------- & ------------ & $(0,041)^{* *}$ \\
\hline Rev & 0,5264499 & 0,518283 & 0,505216 \\
& $(0,153)$ & $(0,149)$ & $(0,157)$ \\
\hline Ch & 0,0165413 & 0,0165313 & 0,0132213 \\
& $(0,000)^{* * *}$ & $(0,000)^{* * *}$ & $(0,000)^{* * *}$ \\
\hline Pt & 0,0081582 & 0,007834 & 0,0058315 \\
& $(0,025)^{* *}$ & $(0,049)^{* *}$ & $(0,190)$ \\
\hline Number of observations & 710 & 710 & 710 \\
\hline
\end{tabular}

$* * *$ _ ** _ * indicate respective risk levels $1 \%-5 \%-10 \%$

- For density of the population: Urbanization has a positive effect on crime against property in the three regressions.

- For income variable: The income variation has still no effect on crime against property no matter the education level introduced in the regression. This result is the same as the case of crime against people and in the case of total crime.

- For primary education ( $\left.\mathbf{e d}_{1}\right)$ variable: The estimation showed that primary education $\left(\mathrm{ed}_{1)}\right.$ has no effect on crime against property.

- For the secondary and higher education $\left(\mathbf{e d}_{2}\right)$ and $\left(\mathbf{e d}_{3}\right)$ : We notice that a higher education level reduces crime level against property. As in the case of crime against people, this result highlights the three types of externality:

-Pecuniary externality: the fact that the higher education level_has a higher impact $(-0$, $36107764)$ than the secondary level of education $(-0,0841608)$. Therefore, the increase of education level increases salary level, hence the reduction of crime against property (a low level of salary pushes the individual to execute a for-profit criminal act= economic crime such as theft). Consequently, cost decreases in the United-States (decrease in internal security expenses).

-Social externality via income inequalities: this externality is interpreted by noticing the effect of unemployment on economic crime. When education level increases legal income, unemployment decreases and consequently its effect on economic crime also decreases.

These results are significant for all the 51 American states (our sample) except for income effect.

- Urbanization accentuates crime under its different forms.

- Crime is justified by a high unemployment rate. 


\section{Macrothink}

Business and Economic Research

ISSN 2162-4860

2018, Vol. 8, No. 4

- The individual income level is not explained by a rise in crime, nor against people nor against property. This result is opposed to the works of Becker (1969), Ehlrich (1973) and Grogger (1998) who suggest that criminal activity is a non-profit activity and confirms the result of F.Puech (2005) as for violent crime.

- Education affects crime negatively, in particular education of secondary and higher levels.

- For total crime, crime against property and crime against people, the higher the education level is the higher deterrence effect is.

- A higher education level reduces any kind of crime but its deterrent effect is more considerable on economic crime and this can be interpreted by the fact that a normal individual doesn't commit generally a violent crime.

- Indeed, for the part of the population aged between 25 and 34 (according to our sample), with a higher secondary level of education, the deterrent effect of higher education is more remarkable and this confirms our hypothesis that the more the education level increases, the more the crime decreases.

\subsection{The Implications of the Study Results}

These results have important implications of economic and social policies, namely from the point of view of arbitration between policy of repression (policy deterrence) and incentive policy (investment in human capital). Indeed, investment in human capital via education represents an effective and complementary deterrent policy to the repressive policy in the different American states.

On the basis of this complementarity, delinquency will only be able to eradicate by police policy such as the increase of the probability of arrest and condemnation via the increase of internal security expenses, but also thanks to human capital accumulation policy via the increase of education public expenses. These expenses can improve the effectiveness of the educational system, producing citizens respecting social norms (education civic externalities) and economic norms (education pecuniary externalities), allowing at the same time to deter crimes against people and crime against property. Therefore, policies increasing schooling (or effectiveness of schooling) should reduce most of crime types by the maximization of positive effects of human capital accumulation within society: increase the preference of legal activities and the opportunity cost of illegal and criminal activities.

These results are interesting to more than one title; the analysis establishes a diagnosis on the state of crime in the United States. It appears that the higher the education level increases the lower crime rate is. Educational level seems, therefore, be the major variable on which economic policy decision decision-makers should act to reduce crime rate. It's a process that extends over time. To ensure adequacy of training in universities and "grandes écoles" and adopt a crime deterrence policy through the implementation of structures able to help install young school-leavers and increase education public expenses. Family life circle doesn't manage to cope with this constraint. The young school-leavers, find in criminal acts a good 
means of re-establishing of socio-economic balance before illegal distribution of income.

\section{Conclusion}

The criminal act is assimilated to an economic act a criminal individual is an economic agent performing a purely economic activity based on a rational calculation comparing the profits and the costs of his activity.

From the results obtained, we can validate the deterrent effect of the accumulation of human capital on the criminal decision. These results were obtained in different American states. Urbanization is a vector that accentuates crime with its different forms. Crime is justified by a high unemployment rate. This result corroborates previous studies such as those of Becker. The level of individual income does not explain the rise in economic or violent crime. This result contrasts, however, with the work of Becker (1969), Ehrlich (1973) and Grogger (1998) who assume that criminal activity is a lucrative activity and confirms the result of F.Puech (2005) when the crime violent. Higher education level reduces any kind of crime in the United-States but its deterrent effect is more considerable on economic crime. The investment in human capital via education represents an effective and complementary deterrent policy to repressive policy.

\section{References}

Becker, G. (1968). Crime and Punishment: An Economic Approach. Journal of Political Economy, 2, 169-217. https://doi.org/10.1086/259394

Carr-Hill, R. A., \& Stern, N. H. (1973). An Econometric Model of the Study and Control of Recorded Offences in England and Wales. Journal of Public Economics, 2.

Chiricos, T. (1987). Rates of Crime and Unemployment: An Analysis of Aggregate Research Evidence. School Problems, 34, 127-140.

Ehrlich, I. (1973). Participation in Illegitimate Activities; A Theoretical and Empirical Investigation. Journal of Political Economy, 81(3), 521-565. https://doi.org/10.1086/260058

Ehrlich, I. (1975). Crime and Education: Education Income and Human Behavior- NBER-

Ehrlich, I. (1975). The Deterrent Effect and Capital Punishment: A Questions of Life and Death. American Economic Review, 65(3), 397-417.

Fajnzleber, P., Lederman, D., \& Loayza, N. (2002). What causes violent crime?. European Economic Review, 46, 1323-1357. https://doi.org/10.1016/S0014-2921(01)00096-4

Fajnzylber, P., \& Lederman, D. L. (2002). Inequality and Violent Crime. Journal of Laws and Economics, 14, 3-36. https://doi.org/10.1086/338347

Fajnzylber, P., Lederman, D., \& Norman, L. (2002b). Inequality and Violent Crime. Journal of Law and Economics, 45, 1-40. https://doi.org/10.1086/338347

Frederic, P., \& Patrick, G. (2005). L'instabilité macroéconomique comme un facteur de criminalité 


\section{Macrothink}

Business and Economic Research ISSN 2162-4860 2018, Vol. 8, No. 4

Gendron, M. (2007). Investissement en capital humain et incidence des crimes à col blanc.

Grogger (1998). Market Wages and Youth Crime. Journal of Labor Economics, 16(4), 756-791. https://doi.org/10.1086/209905

Harris, J. (1970). On The Economics of law and order. Journal of Political Economy. Economic Review, 270-277. https://doi.org/10.1086/259616

Kelly, M. (2000). Inequality of Crime. The Review of Economics Statics, 82, 530-539. https://doi.org/10.1162/003465300559028

Lochner (2004). Education, Work, and Crime: A Human Capital Approach. International Economic Review, 45(3), 811-843. https://doi.org/10.1111/j.0020-6598.2004.00288.x

Lochner, L. (1999). Education, Work and Crime: Theory and Evidence: Working Paper $\mathrm{n}^{\circ} 465$.

Lochner, L. (2007). Education and Crime. University of Western Ontario.

Lochner, L., \& Moretti, E. (2004). The Effets of Education on Crime. Evidence from prison inmates, arrests and self- reports. American Economic Review, 94, 155-89.

https://doi.org/10.1257/000282804322970751

Schotter, A. (1994). Microeconomics: A contemporary approach. French translation.

Sjoquist, D. L. (1973). Property Crime and Economic Behavior: Some Empirical Results. American Economic Review.

Sutherland, E. H. (1949). White Collar Crime. Hot Rinehart and Winston, New York, NY

Usher, D. (1997). Education as a deterrent to Crime. Canadian Journal of Economics, 30, 367-84. https://doi.org/10.2307/136344

\section{Copyright Disclaimer}

Copyright for this article is retained by the author(s), with first publication rights granted to the journal.

This is an open-access article distributed under the terms and conditions of the Creative Commons Attribution license (http://creativecommons.org/licenses/by/3.0/). 